\title{
Investigating the annual behaviour of submicron secondary inorganic and organic aerosols in London
}

\author{
D. E. Young ${ }^{1, *}$, J. D. Allan ${ }^{1,2}$, P. I. Williams ${ }^{1,2}$, D. C. Green ${ }^{3}$, M. J. Flynn ${ }^{1}$, R. M. Harrison ${ }^{4,5}$, J. Yin ${ }^{4}$, \\ M. W. Gallagher ${ }^{1}$, and H. Coe ${ }^{1}$ \\ ${ }^{1}$ School of Earth, Atmospheric and Environmental Sciences, University of Manchester, Oxford Road, Manchester, \\ M13 9PL, UK \\ ${ }^{2}$ National Centre for Atmospheric Science, University of Manchester, Oxford Road, Manchester, M13 9PL, UK \\ ${ }^{3}$ School of Biomedical and Health Sciences, King's College London, London, UK \\ ${ }^{4}$ School of Geography, Earth and Environmental Sciences, University of Birmingham, Edgbaston, Birmingham, B15 2TT, UK \\ ${ }^{5}$ Department of Environmental Sciences/Center of Excellence in Environmental Studies, King Abdulaziz University, Jeddah, \\ 21589, Saudi Arabia \\ *now at: Department of Environmental Toxicology, University of California, Davis, CA, 95616, USA
}

Correspondence to: H. Coe (hugh.coe@manchester.ac.uk)

Received: 17 June 2014 - Published in Atmos. Chem. Phys. Discuss.: 16 July 2014

Revised: 17 April 2015 - Accepted: 8 May 2015 - Published: 11 June 2015

\begin{abstract}
For the first time, the behaviour of non-refractory inorganic and organic submicron particulate through an entire annual cycle is investigated using measurements from an Aerodyne compact time-of-flight aerosol mass spectrometer (cToF-AMS) located at a UK urban background site in North Kensington, London. We show that secondary aerosols account for a significant fraction of the submicron aerosol burden and that high concentration events are governed by different factors depending on season. Furthermore, we demonstrate that on an annual basis there is no variability in the extent of secondary organic aerosol (SOA) oxidation, as defined by the oxygen content, irrespective of amount. This result is surprising given the changes in precursor emissions and contributions as well as photochemical activity throughout the year; however it may make the characterisation of SOA in urban environments more straightforward than previously supposed.

Organic species, nitrate, sulphate, ammonium, and chloride were measured during 2012 with average concentrations ( \pm 1 standard deviation) of $4.32( \pm 4.42), 2.74( \pm 5.00)$, $1.39( \pm 1.34), 1.30( \pm 1.52)$, and $0.15( \pm 0.24) \mu \mathrm{g} \mathrm{m}^{-3}$, contributing $44,28,14,13$, and $2 \%$ to the total non-refractory submicron mass $\left(\mathrm{NR}-\mathrm{PM}_{1}\right)$ respectively. Components of the organic aerosol fraction are determined using positive matrix factorisation (PMF), in which five factors are identified and attributed as hydrocarbon-like OA (HOA), cooking
\end{abstract}

OA (COA), solid fuel OA (SFOA), type 1 oxygenated OA (OOA1), and type 2 oxygenated OA (OOA2). OOA1 and OOA 2 represent more and less oxygenated OA with average concentrations of $1.27( \pm 1.49)$ and $0.14( \pm 0.29) \mu \mathrm{g} \mathrm{m}^{-3}$ respectively, where OOA1 dominates the SOA fraction $(90 \%)$.

Diurnal, monthly, and seasonal trends are observed in all organic and inorganic species due to meteorological conditions, specific nature of the aerosols, and availability of precursors. Regional and transboundary pollution as well as other individual pollution events influence London's total submicron aerosol burden. High concentrations of nonrefractory submicron aerosols in London are governed by particulate emissions in winter, especially nitrate and SFOA, whereas SOA formation drives the high concentrations during the summer. The findings from this work could have significant implications for modelling of urban air pollution as well as for the effects of atmospheric aerosols on health and climate.

\section{Introduction}

Atmospheric aerosols have adverse effects on human health (Pope and Dockery, 2006), air quality (AQEG, 2012), visibility (Watson, 2002), and climate (Boucher et al., 2013). Pollution abatement is therefore important, especially in cities, 
when three-quarters of Europe's population currently live in urban areas, a number that is expected to increase to $80 \%$ by 2020 (EEA, 2010). Regulations on air quality are based on $\mathrm{PM}_{10}$ and, more recently, $\mathrm{PM}_{2.5}$ (particulate matter with aerodynamic diameters less than 10 and $2.5 \mu \mathrm{m}$ respectively; European Union, 2008). A recent study (Aphekom Summary Report, 2011) reported that life expectancy in London could increase by 2.5 months for persons 30 years of age and older if average annual $\mathrm{PM}_{2.5}$ concentrations were decreased in line with the World Health Organization's air quality guidelines to $10 \mu \mathrm{g} \mathrm{m}^{-3}$ (WHO, 2005). $\mathrm{PM}_{1}$ (particulate matter with an aerodynamic diameter less than $1 \mu \mathrm{m}$ ) is beginning to receive greater attention from the air quality community as it is associated with adverse health effects due to the depth within the lungs to which the particles can penetrate, enter the blood stream, and cause damage to other parts of the body (Oberdörster et al., 2005).

Primary and secondary aerosols have both natural and anthropogenic sources (Seinfeld and Pandis, 2006), resulting in their diverse chemical composition, size, and concentration (Pöschl, 2005). In urban areas, primary aerosols from transport, cooking, and solid fuel burning are of great significance (Allan et al., 2010), particularly in the winter when meteorological conditions are such that their concentrations are elevated, resulting in pollution events (Zhang et al., 2007; Huang et al., 2014). In addition, transported air masses frequently influence the UK's atmosphere (Abdalmogith and Harrison, 2005), including polluted air masses from continental Europe and cleaner westerly conditions. Transported pollution typically comprises secondary aerosols, with season having a strong influence on the chemical composition and concentration (Charron et al., 2007). Previous studies highlight the variability in the contribution of both secondary inorganic and organic aerosol (SIA and SOA respectively) to the total mass depending on location (Jimenez et al., 2009). Furthermore, chemical composition varies with location due to a combination of local and regional aerosol sources as well as daily and seasonal meteorological conditions.

The precursors and formation processes of SIA are relatively well understood, particularly as anthropogenic emissions dominate, although concentrations are significantly influenced by regional and transboundary pollution. For example, Abdalmogith and Harrison (2006) estimated that between 2002 and 2004, $88 \%$ of nitrate and $92 \%$ of sulphate in central London originated from the regional background. Due to the non-linear response of SIA concentrations from reductions in precursor emissions, the impacts on formation from changes in emissions are uncertain (AQEG, 2012). In contrast, the complexity of SOA precursors, including the range of atmospheric processing they can undergo, lifetime, and temporal and spatial variability presents a major challenge to understanding and characterising SOA and its formation (Goldstein and Galbally, 2007). Additional variability of SOA sources and formation results from the long distances over which SOA precursors and the resulting aerosols can be transported as well as dependency on meteorological conditions (Martin et al., 2011). Furthermore, SOA evolves in the atmosphere with properties changing with age ( $\mathrm{Ng}$ et al., 2010), meaning our ability to quantify and predict SOA remains limited.

The Aerodyne Aerosol Mass Spectrometer (AMS) measures size-resolved chemical composition of non-refractory submicron particulates with high time resolution (Jayne et al., 2000; Canagaratna et al., 2007). The AMS has demonstrated its versatility in a range of environments across the world (Zhang et al., 2007) and has been used to successfully investigate SOA behaviour (e.g. Jimenez et al., 2009; Heald et al., 2010; Ng et al., 2010; Kroll et al., 2011). Despite its widespread use in such process studies, the instrument is infrequently used for long-term characterisation of aerosols. The related aerosol chemical speciation monitor (ACSM, Ng et al., 2011a), however, is routinely used for long-term measurements of aerosol chemical composition. Here we present a year-long UK urban background data set collected with a compact time-of-flight AMS (cToF-AMS) including results of positive matrix factorisation (PMF) analysis, which is the first time the AMS has been used in this way in an urban environment. The temporal trends and contributions of urban aerosols to $\mathrm{PM}_{1}$ are evaluated and their sources are investigated. In this paper we will focus on the secondary aerosols; though primary organic aerosol (POA) sources are identified in this paper, the behaviour of primary aerosols from these sources will be discussed in subsequent publications.

In Sect. 2 of the paper, the experimental site, instrumentation, and analysis methods utilised in this study are described. In Sect. 3, an overview of the bulk non-refractory $\mathrm{PM}_{1}\left(\mathrm{NR}-\mathrm{PM}_{1}\right)$ components including average mass, diurnal profiles, and seasonality is presented along with a discussion on the factors governing concentrations and temporal trends. In Sect. 4, the components of the organic fraction are investigated using receptor modelling. In Sect. 4.3, we investigate two covarying factors derived from PMF analysis, with the method used to estimate the concentrations of the two factors described in Sect. 4.4. In Sect. 5, the organic components are identified and the results from the previous sections are used to probe the behaviour of urban SOA including temporal trends (Sect. 5.1) and state of oxidation (Sect. 5.2). In Sect. 6, the factors governing pollution events across the year, as well as winter and summer, are assessed through identification of the dominant components of the high concentration events. Finally, Sect. 7 summarises the conclusions from this study on secondary aerosols in London.

\section{Experimental}

\subsection{Site and instrumentation}

The measurements for this study were conducted as part of the Clean Air for London (ClearfLo) Project (www. 
clearflo.ac.uk), a large, multi-institutional collaborative scientific project based in the UK funded by the Natural Environment Research Council (NERC). A suite of state-of-theart instrumentation, measuring aerosols, gases, radicals, and meteorological parameters was deployed for two major intensive observation periods (IOPs) during 2012, with longterm continuous measurements conducted between 2011 and 2013. Measurements were conducted at the ClearfLo urban background site in the grounds of a school in North Kensington $\left(51.521055^{\circ} \mathrm{N}, 0.213432^{\circ} \mathrm{W}\right)$, where a permanent Department for Environment, Food and Rural Affairs (DEFRA) Automated Urban and Rural Network (AURN, http://uk-air. defra.gov.uk/networks/network-info?view=aurn) monitoring station is located. A background site is defined by DEFRA as being "located such that its pollution level is not influenced significantly by any single source or street, but rather by the integrated contribution from all sources upwind of the station" and "be representative for several square kilometres". Situated in a residential area $7 \mathrm{~km}$ to the west of Central London, the sampling site is not influenced by heavily trafficked roads and is representative of background air quality (Bigi and Harrison, 2010). Along with the school buildings, a car park and a relatively large playing field are also located at the site with several large trees both on site and lining the surrounding pavements. Further details on the ClearfLo experimental campaigns and locations are described in Bohnenstengel et al. (2014).

Aerosol chemical composition was measured by the cToFAMS for a full calendar year (11 January 2012-23 January 2013) and by the high-resolution time-of-flight AMS (HR-ToF-AMS) during the two IOPs, which were conducted in the winter (January-February) and summer (July-August) of 2012. The cToF-AMS sampled through a $\mathrm{PM}_{2.5}$ inlet, with a bypass flow of $16 \mathrm{~L} \mathrm{~min}^{-1}$ and split using an asymmetric Y-piece. The HR-ToF-AMS was located in a shipping container containing several other aerosol instruments, where aerosols were sub-sampled from a sampling stack with a flow of $30 \mathrm{~L} \mathrm{~min}^{-1}$ via a $3.5 \mu \mathrm{m}$ cut-off cyclone.

Both AMS instruments operated in the standard configuration and took mass spectra and particle time-of-flight data. An overview of the AMS can be found in Canagaratna et al. (2007) and detailed descriptions of both the cToF-AMS and HR-ToF-AMS can be found in Drewnick et al. (2005) and DeCarlo et al. (2006) respectively. The instrument operation and data analysis procedures pertinent to this study have been described elsewhere (e.g. Allan et al., 2010). The HRToF-AMS operated in both "V" and "W" ion path modes, offering high sensitivity but low mass resolution and low sensitivity but high mass resolution respectively. Only the $\mathrm{V}$ mode ambient data are analysed further here due to their better signal-to-noise ratio. The time resolution of the cToFAMS was $5 \mathrm{~min}$ throughout the measurement period. As the HR-ToF-AMS sampled in an alternating sequence with other black carbon and aerosol volatility measurements using a thermodenuder (Huffman et al., 2008) in the winter, $5 \mathrm{~min}$ averaged ambient data in $\mathrm{V}$ mode were only obtained every $30 \mathrm{~min}$. In the summer, there were no volatility measurements so average data were obtained every $12 \mathrm{~min}$. Both instruments were calibrated using $350 \mathrm{~nm}$ mono-disperse ammonium nitrate particles approximately once a month for the cToF-AMS and weekly during the IOPs for the HR-ToFAMS. Ammonium sulphate calibrations were also performed where possible. The heater bias of the cToF-AMS was tuned to minimise the signal from surface ionised potassium and the filament was run at a lower value than usual in order to prolong the life of the multi-channel plate (MCP). This configuration results in a reduced signal, which in turn reduces the signal-to-noise ratio (Allan et al., 2003).

\subsection{Analysis and quality control of AMS data}

CToF-AMS data were analysed within Igor Pro (Wavemetrics) using the standard ToF-AMS analysis toolkit software package, SQUIRREL (SeQUential Igor data RetRiEval) v1.53. The HR-ToF-AMS data were analysed using SQUIRREL v1.52J and PIKA v1.11J (Sueper, 2008). An average ionisation efficiency (IE) determined from all calibrations was applied to the full data set. Relative ionisation efficiencies (RIEs) of ammonium, nitrate, and sulphate were estimated based on the molar ratios of each species from the ammonium nitrate calibrations (see Table S1 in the Supplement for the ammonium and sulphate RIE values for the cToF-AMS and HR-ToF-AMS). These were compared to particulate sulphate measurements from the URG9000B Ambient Ion Monitor (AIM) from North Kensington (AURN and Particle Numbers and Concentrations Network, http://uk-air.defra.gov.uk/networks/network-info? view=particle) where available (Fig. S1) and indicated that the default RIE of sulphate of 1.2 may not be appropriate for either instrument. As a sulphate calibration was not performed on the HR-ToF-AMS during the winter IOP the RIE was ambiguous, so concentrations were based on those reported by the cToF-AMS, which was calibrated later during the campaign (see Sect. 2.1 in the Supplement for a comparison of the concentrations between the two instruments for the winter IOP and Sect. 2.2 for the summer IOP). This approach, as opposed to using the default RIE of 1.2, was deemed valid as it resulted in a more consistent volume concentration compared with that derived from a differential mobility particle sizer (DMPS) from the winter IOP (Fig. S2), where the volume concentration was estimated using the densities reported by Cross et al. (2007). A timeand composition-dependent collection efficiency (CE) was applied to the data based on the algorithm by Middlebrook et al. (2012). This was also validated for both AMSs by comparing the volume concentration with that derived from the DMPS measurements from the winter IOP (Fig. S2a and d).

Inspection of the data revealed step changes in cToFAMS mass concentrations that coincided with changes in the flowrate, which were mostly due to partial blockages in 

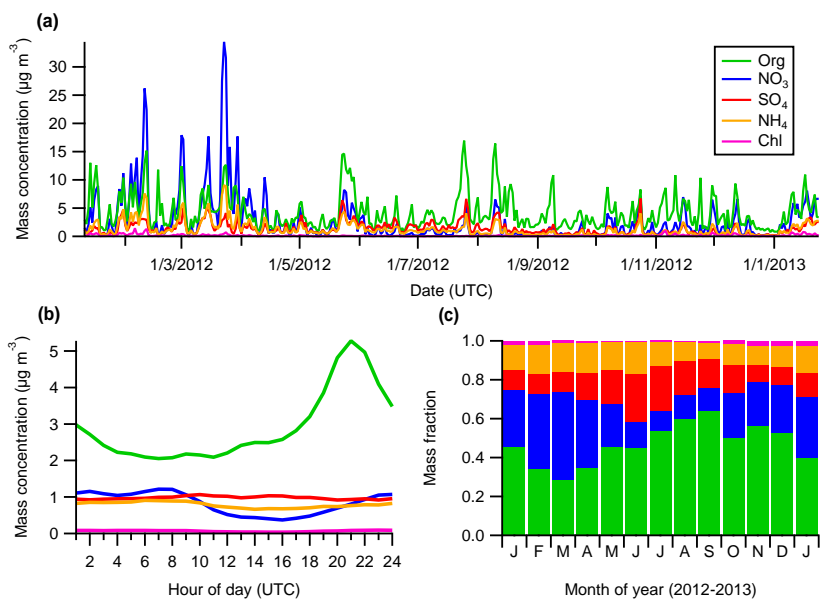

(c)

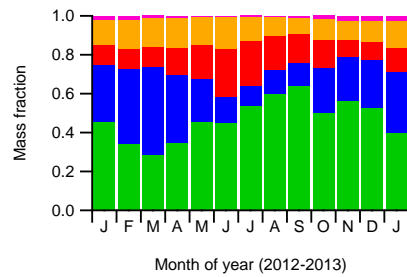

Figure 1. (a) Daily averaged time series of all NR-PM $M_{1}$ species. (b) Median diurnal profiles of all NR-PM 1 species. (c) Average monthly fractional contribution of all species to total NR-PM 1 . The months are grouped as seasons: January 2012, February, December, and January 2013 are in winter; March, April, and May are in spring; June, July, and August are in summer; September, October, and November are in autumn.

the pinhole (see Sect. 1.2 in the Supplement). In each case, the pinhole was either manually cleaned (through sonication in deionised water) or the flow returned to its average rate of $1.3 \mathrm{cc} \mathrm{s}^{-1}$ without intervention. Data were removed if clear mass changes were observed, with distinct start and end points (e.g. 2 June 2012, Fig. S3b). Other data were flagged as suspect if the flow was significantly different from its normal rate (less than $1.2 \mathrm{cc} \mathrm{s}^{-1}$ ) but there were no distinct step changes in mass, e.g. 4 September 2012 (Fig. S3c). The final data set comprised $95 \%$ data that had not been removed or flagged as suspect.

\subsection{Levoglucosan measurements}

Twenty-four-hour $\mathrm{PM}_{2.5}$ samples were collected on quartz fibre filters (Whatman QM-A) at North Kensington during the winter 2012 ClearfLo campaign using a high volume Digitel DHA-80 sampler at a flow of $500 \mathrm{~L} \mathrm{~min}^{-1}$. These samples were analysed for wood smoke marker levoglucosan using a slightly modified version of the method of Yin et al. (2010) and Wagener et al. (2012). In brief, one portion of the Digitel filter sample was spiked with an internal standard (IS), methyl-beta-D-xylopyranoside (from Sigma-Aldrich Ltd), and extracted with dichloromethane and methanol under mild sonication at room temperature. The combined extract was filtered and concentrated down to $50 \mu \mathrm{L}$. One aliquot of the extract was evaporated to near dryness and derivatised by addition of N,O-bis(trimethylsilyl)trifluoroacetamide plus $1 \%$ trimethylchlorosilane (BSTFA $+1 \%$ TMCS) and pyridine at $70^{\circ} \mathrm{C}$ for $1 \mathrm{~h}$ and finally cooled in a desiccator. Quantification was based on the IS and a six-point authentic standard calibration curve, using the selected ion monitoring

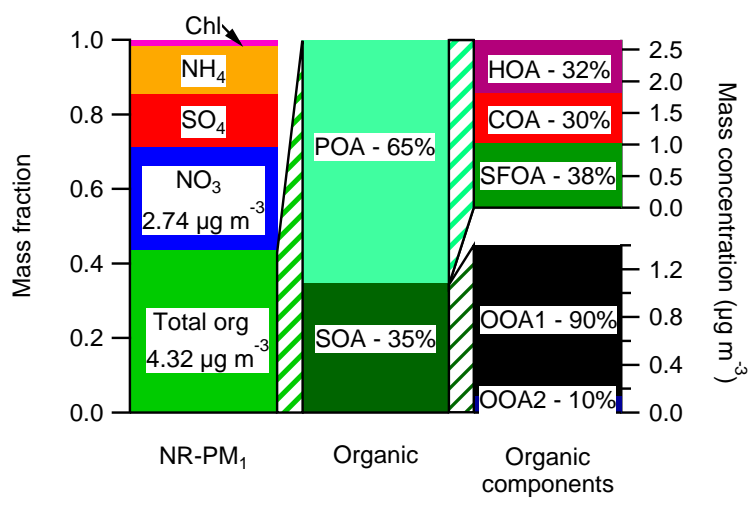

Figure 2. Left: average annual fractional contribution of all species to total NR-PM 1 . The average annual NR-PM 1 concentrations of $\mathrm{SO}_{4}, \mathrm{NH}_{4}$, and $\mathrm{Chl}$ were $1.39,1.30$, and $0.15 \mu \mathrm{g} \mathrm{m}^{-3}$ respectively. Middle: expansion of the organic fraction into its primary and secondary components following PMF analysis. Right top: expansion of the POA fraction into its three components. Right bottom: magnification of the SOA fraction showing its two subtypes. SFOA and $\mathrm{OOA} 2$ refer to $\mathrm{SFOA}_{\text {mod }}$ and $\mathrm{OOA} 2_{\text {mod }}$ respectively. See text in Sect. 4.4 for more details. Note that the organic data plotted in the middle and right bars do not include a period from the summer as discussed in Sect. 4.1 as well as Sects. 4.1 and 4.2 in the Supplement.

mode on an Agilent GC-MS instrument. The ions monitored were 204 and 217 for the IS and 204, 217, and 333 for levoglucosan.

\section{Results}

The daily averaged time series of NR-PM 1 species, their diurnal patterns, and monthly average contributions to total submicron mass are shown in Fig. 1. On average, $\mathrm{PM}_{1}$ composition is dominated by the organic fraction (Org, $44 \%$, Fig. 2) with the remainder of the total mass comprising SIA species. Nitrate $\left(\mathrm{NO}_{3}\right)$ is the largest SIA component, comprising $28 \%$ of the total mass. Sulphate $\left(\mathrm{SO}_{4}\right)$ and ammonium $\left(\mathrm{NH}_{4}\right)$ contribute $14 \%$ and $13 \%$ respectively with a small contribution from non-refractory chloride (Chl, $1 \%)$. The contribution of each species to the total mass varies with time; organics dominate in summer and inorganics dominate in winter, with nitrate contributing up to $45 \%$ of the total mass in spring (Fig. 1c).

Organic species constituted, on average, just under half of the non-refractory submicron mass as measured by the AMS in 2012 (44\%, Fig. 2), with a mean annual concentration $( \pm 1$ standard deviation) of $4.32( \pm 4.42) \mu \mathrm{g} \mathrm{m}^{-3}$. During the year, concentrations at times increased up to, and over, an order of magnitude greater than this value, with a maximum $5 \mathrm{~min}$ concentration of $230 \mu \mathrm{g} \mathrm{m}^{-3}$ observed on 18 February. This is likely a locally sourced event lasting approximately $6 \mathrm{~h}$ as the maximum daily concentration was $16.97 \mu \mathrm{g} \mathrm{m}^{-3}$, observed on 25 July (Fig. 1a). The mean organic concentrations 
and diurnal patterns exhibit little seasonality (Fig. S6a and b respectively); a large evening peak is observed in all diurnal profiles but the number of peaks and their timing during the day vary slightly with season. Although the total mass of organic species exhibits little seasonality, the organic fraction of total $\mathrm{PM}_{1}$ varies with season, being largest in summer and autumn.

The average annual $\mathrm{PM}_{1}$ nitrate concentration was 2.74 $( \pm 5.00) \mu_{\mathrm{g} \mathrm{m}^{-3}}$ with several high concentration episodes occurring throughout the year (Fig. 1a). Peak events occurred mainly during the winter and spring, with a maximum $5 \mathrm{~min}$ concentration of $48.35 \mathrm{\mu g} \mathrm{m}^{-3}$ measured on 23 March. Increases in the concentrations of all species are also observed during these high nitrate events. Averaged across the year, nitrate exhibits a pronounced diurnal pattern with an overnight increase in mass, peaking at 08:00 UTC, with a daytime minimum at 16:00 UTC (Fig. 1b). The overall shape of the diurnal pattern varies little with season although it becomes less pronounced in summer and autumn (Fig. S7b). In contrast, the total nitrate mass varies significantly with season (Fig. S7a), where the greatest concentrations are observed during the spring, which is also when the diurnal pattern is most pronounced due to a large range of concentrations. The lowest concentrations and smallest diurnal range occur during the summer months.

Submicron sulphate represents approximately $25 \%$ of the inorganic fraction, with a mean concentration of 1.39 $( \pm 1.34) \mu \mathrm{g} \mathrm{m}^{-3}$. The maximum $5 \mathrm{~min}$ sulphate concentration measured in 2012 was $12.75 \mu \mathrm{g} \mathrm{m}^{-3}$ which occurred on 2 May. In general, increases in sulphate mass are coincident with increases in concentration of other AMS measured species. In contrast to nitrate, sulphate exhibits little seasonality although it dominates SIA mass in summer, with higher mean concentrations occurring in spring and summer compared to autumn and winter (Fig. S8a). Furthermore, sulphate exhibits little diurnal variation for each season as well as for the whole year (Figs. S8b and 1b).

Almost a quarter of the inorganic mass fraction is comprised of ammonium, with a mean concentration of 1.30 $( \pm 1.52) \mathrm{g} \mathrm{m} \mathrm{m}^{-3}$. Averaged across the year, ammonium exhibits a weak diurnal profile (Fig. 1b). However, this pattern varies with season, with a peak in concentration between 08:00 and 10:00 UTC in all but the summer months (Fig. S9b). The most pronounced diurnal variability occurs in spring, which is also when there is the greatest seasonal mass (Fig. S9a) and maximum concentration of the year $\left(14.23 \mu \mathrm{g} \mathrm{m}^{-3}\right)$. The aerosol was found to be neutral throughout the year as the balance between inorganic cationic and anionic charge was maintained.

As the AMS does not detect chloride salts such as sodium chloride, the chloride measured here is primarily ammonium chloride. Although this represents a very small fraction of SIA, with an average concentration of $0.15( \pm 0.24) \mu \mathrm{g} \mathrm{m}^{-3}$, some seasonal differences are apparent. Chloride exhibits a weak diurnal pattern with slightly higher concentrations at night compared to during the day (Fig. 1b), which changes with season (Fig. S10b). The highest chloride concentrations are in the winter with comparatively low concentrations in the summer (Fig. S10a).

\subsection{Behaviour of bulk $\mathrm{PM}_{1}$ components}

\subsubsection{Organic aerosols}

Weak seasonality of organic aerosols (OA) in Paris has been previously suggested (e.g. Freutel et al., 2013) and observed in organic carbon (OC) measurements in Birmingham (Harrison and Yin, 2008). The lack of seasonality arises because of the balance of sources that govern the total concentration of organic species differently during each season (Zhang et al., 2007) rather than the constancy of any particular source. As well as differences in sources with season, increased organic concentrations in winter are due to low temperatures and reduced atmospheric mixing, whereas in summer similar concentrations are due to increased photochemistry (Martin et al., 2011). In contrast to absolute mass, there are differences in the organic fraction of total $\mathrm{PM}_{1}$ with season, which have been observed in Paris (Crippa et al., 2013a; Freutel et al., 2013), Tokyo (Takegawa et al., 2006), and Zurich (Lanz et al., 2007) and can be attributed to seasonal differences in concentrations of other species such as nitrate. Consistent with previous observations, organics in London exhibit little seasonality both in terms of mass and diurnal profile. Any variations in diurnal pattern across the year are due to both mixing layer height dynamics and the nature of the dominant source. The components of the organic aerosol fraction are discussed in more detail in Sect. 4.

\subsubsection{Nitrate}

The annual cycle of nitrate mass is significantly influenced by season (Martin et al., 2011), driven by emissions of ammonia, which typically peak in the spring (Schaap et al., 2004), as well as temperature and relative humidity (RH), which both control nitrate partitioning (Stelson and Seinfeld, 1982). The diurnal pattern of nitrate in urban locations (e.g. Cork, Dall'Osto et al., 2013; Paris, Freutel et al., 2013) is also largely governed by the semi-volatile behaviour of ammonium nitrate. However, nitrate formation also strongly depends on availability of precursor gases (Ansari and Pandis, 1998) such as nitrogen oxides $\left(\mathrm{NO}_{x}\right)$ and, in particular, ammonia, as emissions in urban environments are small compared to $\mathrm{NO}_{x}$ (NAEI, 2013). Although some non-agricultural sources of ammonia are known (Sutton et al., 2000), their strengths and trends are not well understood. Pollution from continental Europe has also been identified as an important contributor to particulate concentrations in many regions (e.g. Manchester, Martin et al., 2011; Paris, Freutel et al., 2013) with the highest nitrate concentrations occurring over 
Table 1. Average annual sulphate concentrations (in $\mu \mathrm{g} \mathrm{m}^{-3}$ ) from two UK locations measured between 2001 and 2012 as part of the AURN and Particulates networks. London North Kensington is an urban background monitoring site and Harwell is a rural background monitoring site.

\begin{tabular}{|c|c|c|}
\hline \multirow[b]{2}{*}{ Year } & \multicolumn{2}{|l|}{ Location } \\
\hline & $\begin{array}{r}\text { London } \\
\text { North Kensington }\end{array}$ & Harwell \\
\hline 2012 & $1.39^{\mathrm{a}}, 1.21^{\mathrm{b}, *}$ & - \\
\hline 2011 & $2.2^{\mathrm{b}}$ & - \\
\hline 2010 & $2.3^{\mathrm{c}}$ & $1.6^{\mathrm{c}}$ \\
\hline 2009 & $1.7^{\mathrm{c}}$ & $1.3^{\mathrm{c}}$ \\
\hline 2008 & $2.6^{\mathrm{c}}$ & $2.4^{\mathrm{c}}$ \\
\hline 2007 & $2.8^{\mathrm{c}}$ & $2.4^{\mathrm{c}}$ \\
\hline 2006 & $3.5^{\mathrm{c}}$ & $3^{\mathrm{c}}$ \\
\hline 2005 & $3^{c}$ & $2.4^{\mathrm{c}}$ \\
\hline 2004 & $3^{c}$ & $2.3^{\mathrm{c}}$ \\
\hline 2003 & $2.6^{\mathrm{c}}$ & $2.4^{\mathrm{c}}$ \\
\hline 2002 & $3.1^{\mathrm{c}}$ & $2.3^{\mathrm{c}}$ \\
\hline 2001 & $3.1^{\mathrm{c}}$ & $2.1^{\mathrm{c}}$ \\
\hline $\begin{array}{l}\text { AMS } \\
\text { Ambient } \\
\text { courtesy } \\
\text { Partisol } 2 \\
\text { courtesy } \\
\text { hon-sea- }\end{array}$ & $\begin{array}{l}\text {, ClearfLo, this study. } \\
\text { Monitor (AIM) }\left(\mathrm{PM}_{10}\right) \text {, } \\
\text { Dr. D. Green). }{ }^{\mathrm{C}} \text { Thermo } \\
\text { ion chromatography (PI } \\
\text { Dr. D. Green). }{ }^{*} \text { Calcula } \\
\text { sulphate. }\end{array}$ & $\begin{array}{l}\text { URG 9000B } \\
\text { KCL } \\
\text { cientific } \\
\text { 10), KCL } \\
\text { d }\end{array}$ \\
\hline
\end{tabular}

northwestern Europe during pollution episodes (Morgan et al., 2010).

Consistent with previous UK measurements (Harrison and Yin, 2008; AQEG, 2012), the highest concentrations in this study occurred in spring. Although more pronounced in winter and spring, the overall shape of the diurnal profile does not change with season, indicating the strong semi-volatile behaviour of nitrate. Also consistent with previous studies (e.g. Abdalmogith and Harrison, 2005), increased nitrate concentrations occur in air masses influenced by continental northwestern Europe, indicating the importance of transboundary pollution. Nitrate concentrations are therefore governed by a combination of season, ambient conditions, availability of precursor emissions, and air mass trajectory rather than any one factor. Consequently, it was not possible to establish simple metrics that could be used to predict nitrate concentrations, highlighting the need for detailed modelling of aerosol chemistry and thermodynamics to accurately predict nitrate concentrations.

\subsubsection{Sulphate}

Sulphate concentrations have been decreasing at both urban and rural UK locations for at least the last 10 years (as summarised in Table 1) due to decreasing $\mathrm{SO}_{2}$ emissions (Monks et al., 2009). However, sulphate concentrations respond non-linearly to reductions in $\mathrm{SO}_{2}$ emissions (Megaritis et al., 2013). The mean sulphate concentration $\left(1.39 \mu \mathrm{g} \mathrm{m}^{-3}\right)$ measured by the AMS in 2012 is comparable to the nonsea-salt sulphate $\left(1.21 \mathrm{\mu g} \mathrm{m}^{-3}\right)$ calculated from AIM measurements also at North Kensington. The 2012 AMS measurements are therefore consistent with the trend of decreasing sulphate concentrations observed at sites at North Kensington and Harwell. Similar to the findings of Harrison et al. (2012) and Abdalmogith and Harrison (2006), sulphate exhibits little seasonality and diurnal variation, thus emphasising the importance of regional pollution.

\subsubsection{Ammonium}

Changes in the diurnal profile and total mass of ammonium with season are very similar to those of nitrate and, to a lesser extent, sulphate (Morgan et al., 2009; Bressi et al., 2013). The springtime peak in concentrations is governed by the greater availability of ammonia and favourable meteorological conditions.

\subsubsection{Chloride (non-refractory)}

The seasonal variation and diurnal pattern of chloride is attributed to the semi-volatile nature of ammonium chloride as well as planetary boundary layer dynamics where low concentrations are expected during the summer due to increased mixing depth. The availability of ammonia will also govern the concentration of chloride. In addition, increased chloride concentrations in the winter could be attributable to increased coal combustion during this period (Sun et al., 2013).

\section{Positive matrix factorisation analysis}

To investigate the components and temporal trends of the organic fraction, PMF (Paatero and Tapper, 1994; Lanz et al., 2007) was applied to the organic matrix from the year-long cToF-AMS data set, which is the first time PMF has been applied to a data set of this duration from an urban environment. Separating long-term data into seasons before performing factorisation analysis may be used to reduce seasonal phenomena affecting the retrieved factors, such as minimising the influence of variations in photochemistry, and also to address known PMF limitations such as mixing between factors. However, splitting the data into seasons is subjective, resulting in a bias of the retrieved factors and loss of information on annual trends of potential OA components.

Identification of key organic components can also be achieved by using the related multilinear engine ME-2, for which a protocol for the AMS is currently available (Canonaco et al., 2013) and has been found to produce more representative results in some circumstances (e.g. Lanz et al., 2008), particularly when temporal covariation of factors arises. However, a priori knowledge by way of factor profiles and/or time series is required to utilise ME-2, so in principle it is preferable to obtain a factorisation without a priori assumption, which is achieved in this study by way of uncon- 
strained PMF analysis. Furthermore, several of the factorisation problems that ME-2 overcomes when applied to data from the ACSM (Ng et al., 2011a) compared to the AMS are related to the fact that the ACSM has much lower signal-tonoise ratio (approximately by a factor of 40). We present the results from PMF analysis here to compare with earlier work and as a first stage in any further analysis. Furthermore, as we will show in the data presented, temporal covariation of factors can be overcome by careful scrutiny of the data as well as from the use and support of associated measurements such as from the HR-ToF-AMS.

\subsection{Data preparation}

PMF was performed on the organic data matrix for the yearlong data set from the cToF-AMS and for the winter and summer periods when the HR-ToF-AMS was operating. The data preparation for all three data sets followed the recommended procedures as described by Ulbrich et al. (2009). However, for the final PMF solution, the summer period was removed from the cToF-AMS data set, as the mass spectrometer was mistakenly retuned for this period, which caused problems for the factorisation. The changes in the instrumental settings were evident in the data as the concentrations of several of the factors derived from PMF analysis increased simultaneously with a step change in the heater bias. However, due to the nature of the affected factors and the timing of the instrumental changes, it was not possible to calculate a reliable scaling factor to apply to the data from this period. The reader is directed to Sect. 4.1 and 4.2 in the Supplement for more details regarding the data pre-treatment and quality assurance, including the identification and removal of problematic data around the summer IOP. In addition to the standard methods, isotopes were not included in the HR-ToF-AMS organic matrix. The peaks at $m / z, 30$ and 46 were removed from the matrix, as they were not deemed to have been successfully retrieved using PIKA. APES light v1.05 (Sueper, 2008) was used for the elemental analysis of the HR-ToF-AMS PMF (HR-PMF) factors.

\subsection{Factorisation results}

A five-factor solution to the PMF analysis was shown to be optimum for the cToF-AMS data set. The details of the choice of factors and solution criteria can be found in the Supplement Sect. 4.3. The reader is referred to Sect. 5 in the Supplement for the HR-PMF solution criteria, where fivefactor solutions were chosen for both the winter and summer IOPs (Sects. 5.1 and 5.2 in the Supplement respectively). The cToF-AMS PMF (cToF-PMF) solution criteria are briefly outlined here.

The five-factor solution resulted in a better separation of the mass spectral profiles compared to the four-factor solution, with improvements to diagnostics, such as $Q / Q_{\text {expected, }}$ used to assess the quality and suitability of a solution set.

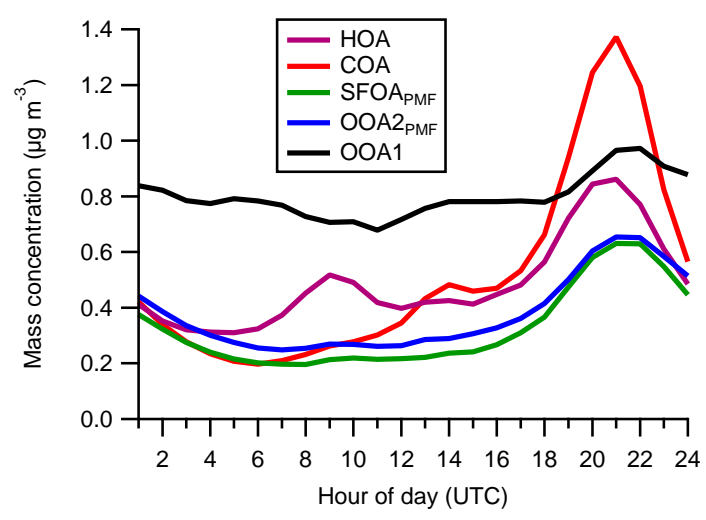

Figure 3. Median diurnal profiles for each of the five PMF factors. Note that these data do not include a period from the summer (see Sect. 4.1).

The six-factor solution was discarded due to the similarity of several factors (spectra and time series). The seven-factor solution was also discarded due to its significant dependency on the initialisation seed (unlike the solutions with fewer factors) as well as the production of a factor that did not appear physically meaningful. The "fPeak" parameter was used to explore the rotational ambiguity of the five-factor solution with the most central solution (fPeak $=0$ ) chosen for further analysis. Additional measurements were used to validate the chosen solution and for attribution of the factors.

Three of the five PMF factors were clearly identifiable: hydrocarbon-like OA (HOA), cooking OA (COA), and type 1 oxygenated OA (OOA1). As the remaining two factors (labelled here as SFOAPMF for solid fuel OA and OOA2PMF for type 2 oxygenated $\mathrm{OA}$ ) exhibited similar temporal features, notably the diurnal pattern (Fig. 3) with an evening peak in concentration, they are investigated and addressed in detail in the following sections.

\subsection{Identifying PMF limitations}

The similarity of the diurnal patterns of SFOAPMF and OOA2 2 PMF is likely due to the nature of the aerosols; SFOAPMF is likely emitted from domestic space heating, an activity that occurs in the evening. OOA2 $\mathrm{PMF}$ is typically thought to be semi-volatile oxygenated OA and will preferentially partition to the particle phase when temperatures are low and RH is high, again most likely in the evening. Conversely, the temporal covariation of the PMF solution could result in partial mixing of these two factors (Crippa et al., $2013 \mathrm{~b}$ ) leading to the identification of an OOA2-BBOA factor (Crippa et al., 2013a), where BBOA is biomass burning OA. However, a clearer separation of such factors was obtained through combined AMS and proton-transfer reaction mass spectrometry (PTR-MS) PMF analysis (Crippa et al., 2013b). 
Table 2. Time series comparison of the PMF factors from the cToFAMS and HR-ToF-AMS for the winter IOP.

\begin{tabular}{llrr}
\hline cToF-PMF factor & HR-PMF factor & Slope & Pearson's $r$ \\
\hline HOA & HOA & 0.95 & 0.90 \\
COA & COA & 0.58 & 0.89 \\
SFOAPMF & SFOA1 & 0.80 & 0.87 \\
SFOAPMF & SFOA2 & 0.85 & 0.72 \\
SFOAPMF & Combined SFOA & 0.52 & 0.90 \\
OOA2PMF & OOA & 0.12 & 0.16 \\
OOA1 & OOA & 0.90 & 0.91 \\
OOA2 $P M F+$ OOA1 & OOA & 1.02 & 0.69 \\
SFOAPMF+ OOA2PMF & Combined SFOA & 0.93 & 0.89 \\
\hline
\end{tabular}

The mass spectral profiles and time series of the cToFPMF factors are compared to the winter IOP HR-PMF factors, as factor retrieval from HR-ToF-AMS data is more robust with significantly reduced rotational ambiguity and improved separation of factors as individual ion signals at the same nominal mass-to-charge ratio $(\mathrm{m} / \mathrm{z}$ ) are included (see Sect. 6 in the Supplement for comparisons of the mass spectra and time series from the winter and summer IOPs where available). In general, there is good correlation between most factors from the two instruments (Pearson's $r$ of $0.69-0.90$, Table 2). However, the concentration of the combined SFOA factors from the winter HR-PMF data set is approximately double that of the cToF-PMF SFOAPMF factor. A near equal concentration of SFOA from both AMSs is achieved when the cToF-PMF OOA2 $\mathrm{PMF}$ is combined with the SFOA $\mathrm{PMF}$ and correlated with the sum of HR-PMF SFOA factors. This suggests that most of the SFOA $A_{P M F}$ mass measured by the cToF-AMS is being assigned to OOA2 ${ }_{\mathrm{PMF}}$ in PMF; the total SFOA mass could therefore be up to a factor of 2 greater than previously estimated.

If SFOA represents all of levoglucosan and other similar species, we might expect good correlation between SFOA and levoglucosan to exist. As org60 (the organic fraction at $\mathrm{m} / \mathrm{z} 60$ ) has contributions from fatty acids arising from cooking primary OA emissions (Mohr et al., 2009) and carboxylic acids from SOA (e.g. DeCarlo et al., 2008), it is not expected that org60 and levoglucosan would correlate exactly when compared. SFOAPMF and SFOAPMF + OOA2 2 PMF are compared to 24-hour filter measurements of levoglucosan from the winter IOP. SFOA $\mathrm{PMF}_{\mathrm{POA}}+\mathrm{OO} 2_{\mathrm{PMF}}$ correlates better with levoglucosan than SFOAPMF on its own (Pearson's $r$ of 0.74 and 0.71 respectively), suggesting that some of the additional variance is carried by a levoglucosan contribution to OOA2 $\mathrm{PMF}$. Furthermore, org60 correlates slightly better with levoglucosan than SFOAPMF (Pearson's $r=0.73$ ), again suggesting that $\mathrm{SFOA}_{\mathrm{PMF}}$ is not capturing all the variability of levoglucosan. However, it is unlikely that this is the full explanation as the $m / z 60$ signal of OOA2 $\mathrm{PMF}$ is relatively small. The possibility that $\mathrm{OOA} 2_{\mathrm{PMF}}$ could be an overlap of what is OOA1 in the summer and an aged SFOA in the winter has been explored but correlations between OOA2PMF and nitrate suggest that this is not likely to be the case.

This is not to suggest that all OOA2 factors contain some contribution of SFOA. However, if SFOA is convolved with OOA2, as is the case in this study, it is possible to estimate the proportion of SFOA convolved with OOA2 with the support of additional measurements. In this study we have shown that comparisons of measurements from the two AMSs highlighted a large difference in SFOA concentrations, which was further supported by levoglucosan measurements and those from the cToF-AMS itself such as org60. Improved separation of OA factors may be achieved in the future, particularly in the absence of supporting measurements, from the application of ME-2 to similar data sets such as those from the ACSM. However, further work is therefore required to better resolve the issues arising from PMF analysis regarding the separation of OA in to its primary and secondary constituents, particularly for long-term data sets.

\subsection{Estimating concentrations of convolved factors}

We infer from the correlations discussed in Sect. 4.3 that nearly all the SFOA $A_{\mathrm{PMF}}$ is assigned to $\mathrm{OOA} 2_{\mathrm{PMF}}$ during the winter IOP, where the proportion of SFOAPMF that is convolved with $O \mathrm{OA}_{\mathrm{PMF}}$ can be determined using the relationship between SFOA ${ }_{P M F}$ and $\mathrm{OOA}_{\mathrm{PMF}}$ from the winter. Both factors have similar, strong diurnal profiles, the effect of which is reduced by using daily averages of each factor in the following equation:

$\mathrm{OOA} 2 \mathrm{PMF}=a \cdot \mathrm{SFOA} \mathrm{PMF}+\mathrm{OOA} 2_{\mathrm{noSF}}$,

where $a$ is the gradient of an orthogonal distance regression fit, equal to 0.86 , and $\mathrm{OOA} 2_{\text {noSF }}$ is the intercept which indicates the amount of OOA2 $\mathrm{PMF}$ without a solid fuel signature. The remainder is the SFOAPMF assigned to OOA2PMF during the PMF analysis and is estimated based on the gradient of the fit. The SFOA and OOA2 concentrations, SFOA mod and $\mathrm{OOA} 2_{\text {mod }}$ respectively, can therefore be calculated using the following equations:

$$
\begin{aligned}
& \mathrm{SFOA}_{\mathrm{mod}}=\mathrm{SFOA}_{\mathrm{PMF}}+\left(a \mathrm{SFOA}_{\mathrm{PMF}}\right), \\
& \mathrm{OOA} 2_{\mathrm{mod}}=\mathrm{OOA}_{\mathrm{PMF}}-\left(a . \mathrm{SFOA}_{\mathrm{PMF}}\right),
\end{aligned}
$$

where OOA2 $2_{\text {mod }}$ in Eq. (3) is equivalent to OOA2 $2_{\text {noSF }}$ in Eq. (1). The relationship based on the winter correlation does not hold true for the whole year and so the annual estimations are improved by using the relationship derived between the daily averages of OOA2 $\mathrm{PMF}$ and SFOAPMF from December 2012 to January 2013, where $a$ is equal to 0.52 . However, instrument maintenance (changes in instrument tuning during the summer and change of the MCP in April) will likely add some variation to these estimates. Therefore, the concentrations up until the summer period are estimated using the relationship from the 2012 winter IOP and the concentrations after the summer are estimated using the December 2012January 2013 relationship. The estimated concentrations of 


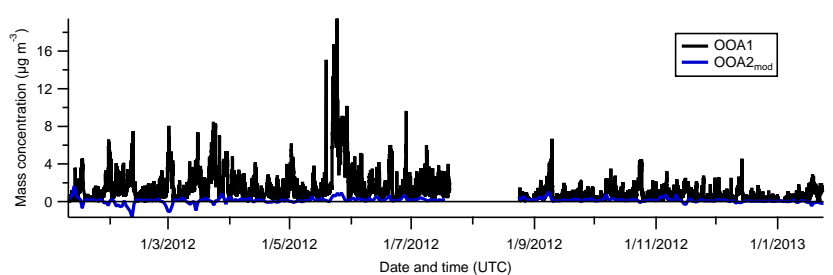

Figure 4. Time series of OOA 1 and OOA $2_{\bmod }$, where OOA $2_{\bmod }$ is the daily average.

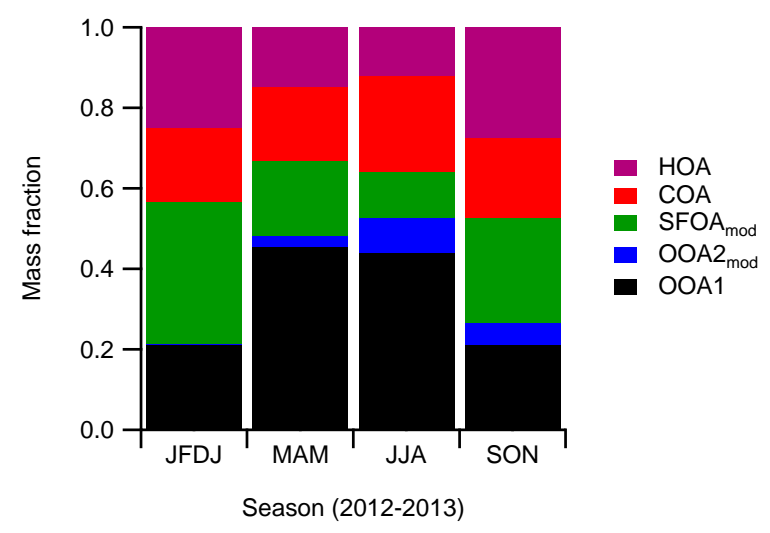

Figure 5. Seasonal fractional contributions of the PMF factors to total OA mass, with revised masses (see Sect. 4.4). As discussed in Sect. 4.1 , a period from the summer is not included in these data.

$\mathrm{OOA} 2_{\text {mod }}$ and $\mathrm{SFOA}$ mod are used for further analyses. Figure 4 shows the retrieved OOA 2 mod is dominated by noise, with an average OOA $2_{\text {mod }}$ concentration of $0.12 \mu \mathrm{g} \mathrm{m}{ }^{-3}$ and standard deviation of $0.46 \mu \mathrm{g} \mathrm{m}^{-3}$ during the winter IOP. The standard deviation provides a measure of uncertainty in our retrieval of OOA2 mod and $\mathrm{SFOA}_{\text {mod }}$ using this approach.

\section{Attribution and contributions of organic components}

Attributing the PMF factors to different organic sources and components allows the organic fraction to be split in to POA and SOA and their contribution to total organic mass to be assessed. The behaviour of urban SOA can then be investigated. The HOA, COA, and $\mathrm{SFOA}_{\text {mod }}$ factors identified in the previous sections are grouped as POA, and OOA1 and $\mathrm{OOA} 2$ mod are grouped as SOA. The primary fraction has the greatest contribution from $\mathrm{SFOA}_{\text {mod }} 38 \%$ (Fig. 2), with smaller contributions from HOA $(32 \%)$ and COA $(30 \%)$. The secondary fraction is dominated by OOA $1(90 \%)$ with only a small contribution from OOA $2_{\text {mod }}(10 \%)$.

The greatest contribution of the organic components to total OA mass, which does not include some of the summer period (see Sect. 4.1), is from OOA1 (31\%), followed by $\mathrm{SFOA}_{\bmod }(25 \%)$, HOA $(21 \%)$, and COA $(19 \%)$. The remainder comprises OOA $2_{\text {mod }}(4 \%)$. During 2012, POA and SOA contributed 65 and $35 \%$ to total OA respectively
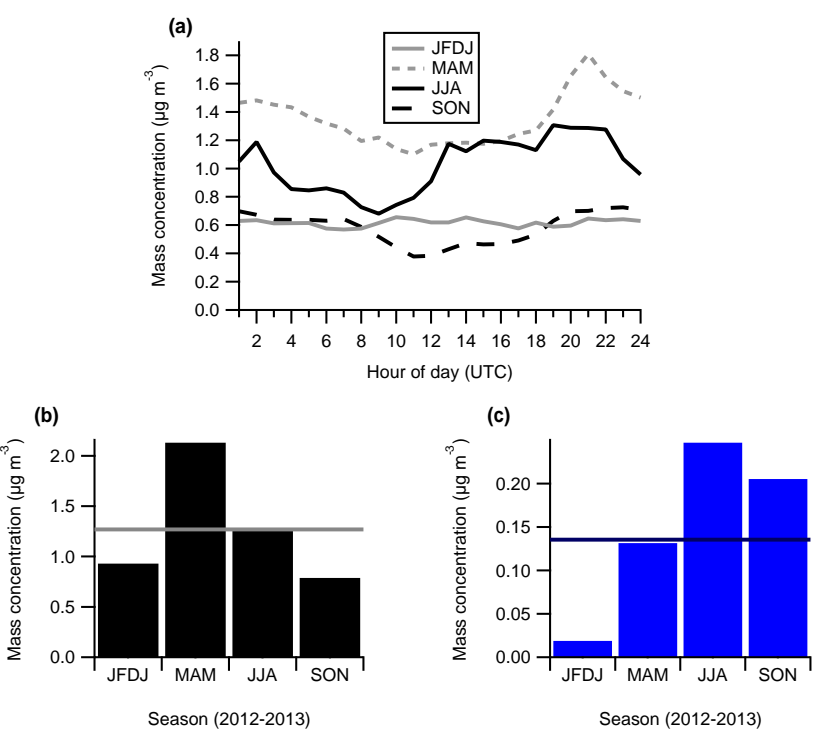

Figure 6. (a) OOA1 seasonal median diurnal profiles. (b) Average seasonal concentration of OOA1, with the annual average denoted by the thick horizontal line. (c) Average seasonal concentration of OOA 2 mod, with the annual average concentration denoted by the thick horizontal line, both estimated in Sect. 4.4. Note that these data do not include the summer period (see Sect. 4.1).

(Fig. 2). However, the contribution of POA and SOA to total OA changes with season: SOA contributes just over $50 \%$ on average during the spring and summer (Fig. 5). The smaller annual contribution from SOA could therefore be partly due to the omitted summer data, in which SOA dominates the mass fraction. However, the mean (and standard deviation) ozone mixing ratio was not found to be statistically significantly different between the 5-week period not included in PMF analysis and the whole June, July, and August period, suggesting the data that are included in the analysis are representative of the data that were removed.

\subsection{The behaviour of secondary organic aerosol in London background air}

The average ( \pm 1 standard deviation) OOA1 concentration observed was $1.27( \pm 1.49) \mu \mathrm{g} \mathrm{m}^{-3}$, with a maximum $5 \mathrm{~min}$ concentration of $19.5 \mu \mathrm{g} \mathrm{m}^{-3}$ measured on 24 May 2012 . OOA1 does not exhibit a discernible diurnal pattern (Fig. 3); the only change with season is by way of concentration (Fig. 6a), suggestive of aged aerosol of a regional nature. The peak in concentrations occurs in spring, where the average concentration is more than double that of the autumn and winter and 1.7 times greater than the summer (Fig. 6b). This springtime peak is consistent with secondary OC measurements in Birmingham (Harrison and Yin, 2008).

In comparison, the OOA 2 mod concentration averaged 0.14 $( \pm 0.29) \mu \mathrm{g} \mathrm{m}^{-3}$ over the year, with maximum daily concentrations occurring in the summer. The seasonal trend of 
$\mathrm{OOA} 2_{\text {mod }}$ is in keeping with it being secondary in nature with concentrations increasing during the summer (Fig. 6c) when photochemical processes and emissions of biogenic volatile organic compounds (VOCs) (Dunmore et al., 2015) are greatest.

Several high concentration events lasting 3-8 days are observed in both OOA 1 and OOA $2_{\text {mod }}$ time series (Fig. 4) such as in May (peaking on 27 May) and to a lesser extent September (peaking on 8-9 September). The event in May is associated mostly with easterly conditions, likely the result of imported pollution. The September event is associated with a high-pressure system centred just off the southwest UK coast with another high-pressure system over continental Europe the following day. This resulted in an increase in concentrations in a stagnant air mass with additional imported pollution on 9 September.

\subsection{SOA chemistry and oxidation state}

SOA forms in the atmosphere from the gas-phase oxidation of a number of VOCs (e.g. Goldstein and Galbally, 2007), which can be anthropogenic or biogenic in origin. SOA comprises a mixture of organic compounds with differing volatilities (Donahue et al., 2012) which partition between the gas and particle phases. SOA therefore exists across a variety of chemical states, thus increasing its chemical complexity. As bulk chemical characterisation of aerosols can be obtained from the AMS, several metrics and graphical representations of the data are used to investigate OA. The information gleaned from such metrics can be used to better inform models on SOA characteristics to improve the quantification and prediction of SOA.

One such metric for describing and explaining OA evolution in the atmosphere is the $f_{44}$ vs. $f_{43}$ space (Morgan et al., 2010; $\mathrm{Ng}$ et al., 2010), where $f_{44}$ and $f_{43}$ are the ratios of the organic signal at $m / z 44$ and 43 to the total organic signal in the component mass spectrum respectively. The degree of oxidation is inferred from the $f_{44}$ value and the range of precursors is suggested by the $f_{43}$ values. Other metrics include the use of oxygen-to-carbon $(\mathrm{O}: \mathrm{C})$ and hydrogento-carbon $(\mathrm{H}: \mathrm{C})$ ratios in Van Krevelen space which reveals changes in functionality and therefore the likely degree of processing the aerosol has undergone (Heald et al., 2010). Kroll et al. (2011) combined these ratios to derive the oxidation state of carbon and thus describe OA chemistry. Furthermore, the chemical evolution of organic aerosol can be analysed by using the oxidation state along with volatility in the two-dimensional volatility-oxidation space (2D-VBS, Donahue et al., 2012). Despite their differences, these metrics can all be used to describe the evolution of gas-phase organic compounds through to semi-volatile OA and up to the most oxidised OA with low volatility, concluding that atmospheric processing of fresh OA results in similarly aged and highly oxidised OA.
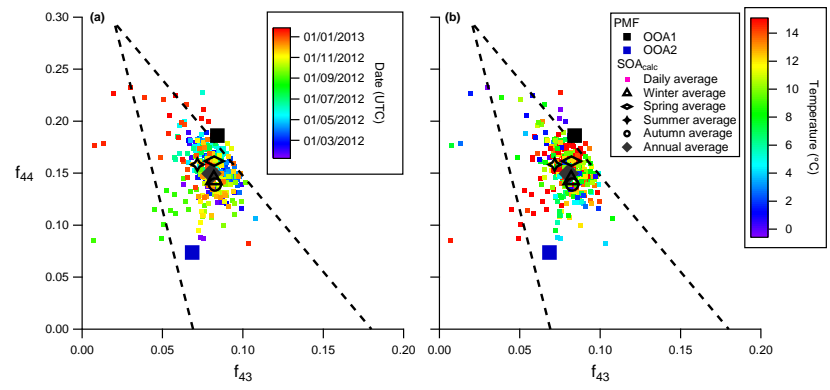

Figure 7. Daily averaged SOA within $f_{44}$ vs. $f_{43}$ space coloured by time (a) and temperature (b), where $f_{44}$ and $f_{43}$ refer to $m / z 44: \mathrm{SOA}_{\text {calc }}$ and $m / z 43: \mathrm{SOA}_{\text {calc }}$ respectively. See text for more details. Daily averaged temperatures ranged from -0.5 to $26^{\circ} \mathrm{C}$, although they are only coloured here up to a maximum of $15^{\circ} \mathrm{C}$ for clarity. Average annual and seasonal $f_{44} / f_{43}$ values for SOA are denoted in the legend. OOA1 and OOA2 PMF factors are also plotted. The outline of the triangle as defined by $\mathrm{Ng}$ et al. (2010) is shown by the dashed black lines. Note that the organic data do not include the summer period (see Sect. 4.1).

To characterise northern hemispheric OA and its evolution in the atmosphere, $\mathrm{Ng}$ et al. (2010) compiled ambient AMS data from numerous urban and rural ground-based measurement campaigns of varying duration (from a few days up to 5 weeks), occurring during different seasons. Morgan et al. (2010) investigated the organic chemical evolution through various airborne measurement campaigns, tracking individual air masses and crossing a range of European sites during different meteorological conditions. Data from both studies exhibited a range of $f_{44}$ and $f_{43}$ values, reflecting the different photochemical ages and sources. However, all data were found to lie within a very well-defined triangular region in $f_{44}$ vs. $f_{43}$ space with OOA1 and OOA2 clustering in discrete regions of the triangular space. This indicated that irrespective of source, atmospheric processes result in the convergence of all ambient OA to chemically similar, highly aged SOA. The most processed OA, with high $f_{44}$ values, in both studies were from rural/remote locations and generally occurred during the summer or during periods of elevated temperatures and greater photochemistry. To further investigate $\mathrm{OA}$ evolution and the corresponding changes in chemical composition, $\mathrm{Ng}$ et al. (2011b) transformed the $f_{44}$ vs. $f_{43}$ triangle into the Van Krevelen diagram (so called VKtriangle). The ambient data from $\mathrm{Ng}$ et al. (2010) fall within a narrow range within the VK-triangle, whereas two urban data sets from different seasons fall in a narrow linear area (El Haddad et al., 2013).

In contrast to the above studies, the measurements in this study are from a single location over the course of 1 year. In order to investigate trends within the secondary component of OA, the PMF-derived primary components (SFOA $_{\text {mod, }}$, $\mathrm{HOA}$, and COA) are subtracted from the total organic aerosol matrix with the remainder assumed to be secondary (here- 
after termed $\left.\mathrm{SOA}_{\text {calc }}\right)$. Furthermore, to assess the degree of oxidation of the SOA in London the contribution of the primary components to $m / z 44$ and 43 are subtracted, so the ratio of $m / z 44: \mathrm{SOA}_{\text {calc }}$ to $m / z 43: \mathrm{SOA}_{\text {calc }}$ can be determined. When plotted in $f_{44}$ vs. $f_{43}$ space, the majority of the data in this study fall within the triangular space defined by $\mathrm{Ng}$ et al. (2010) with the average value falling in the OOA1 region (Fig. 7). Along with the range of $f_{44}$ values, correlations with temperature and time can elucidate the extent to which the aerosol is oxidised; in general, temperatures are elevated and photochemistry is greatest in the summer. Figure 7 illustrates the $f_{44}$ vs. $f_{43}$ space for $\mathrm{SOA}_{\text {calc }}$ coloured as a function of time (Fig. 7a) and temperature (Fig. 7b). SOA calc exhibits little seasonality: spring and summer averages have only a slightly higher ratio than autumn and winter, with this variation occurring within a distinct area of the $f_{44}$ vs. $f_{43}$ space. There is also little evidence for a temperature trend (Fig. 7b).

OOA 1 and OOA 2 are thought to represent end members of OA aging from photochemical processing (Jimenez et al., 2009): OOA 1 is more oxygenated and highly aged compared to the fresher and less photochemically processed OOA2. The $f_{44}$ and $f_{43}$ for the two OOA components identified from PMF analysis in this study, which are fixed factors over the whole 1-year period, are therefore also plotted within the $f_{44}$ vs. $f_{43}$ space to further constrain the degree of oxidation of what is hypothesised to be London SOA. The two subtypes are found to fall within their respective range of $f_{44}$ values expected for each of the two subtypes, with higher $f_{44}$ and $f_{43}$ for OOA1 than OOA2. Using the relationship between $f_{44}$ and $\mathrm{O}: \mathrm{C}$ for unit mass resolution data from Aiken et al. (2008), the estimated $\mathrm{O}: \mathrm{C}$ for the long-term OOA $2_{\mathrm{mod}}$ and OOA 1 factors are 0.36 and 0.79 respectively. In comparison, for the summer IOP there is only a small difference between the $\mathrm{O}: \mathrm{C}$ ratio of OOA2 and OOA1 (0.44 and 0.52 respectively) obtained from HR-PMF. Here, OOA1 has a much lower ratio compared to other urban studies (e.g. Sun et al., 2011; Mohr et al., 2012).

While the concentration of SOA varies through the year, the extent of SOA oxidation shows no variability as a function of time of year or temperature and remains within a very narrow range of values. This could be explained, in part, by the geographical position of London, which leads to influences from both local sources and transported air masses from all directions. SOA in London forms from a variety of precursors across the year (Dunmore et al., 2015), and the contributions of different precursors will change significantly with season. In addition, the greater photochemistry during the summer results in an increase in SOA mass. However, the fraction of oxygen per molecule does not vary as the increase in locally produced fresh SOA likely masks any increase in the oxidation of transported material resulting in chemically similar SOA throughout the year. Whether this extends to similar urban background sites in other locations remains to be determined, but if so it makes a characterisation of SOA in urban environments more straightforward
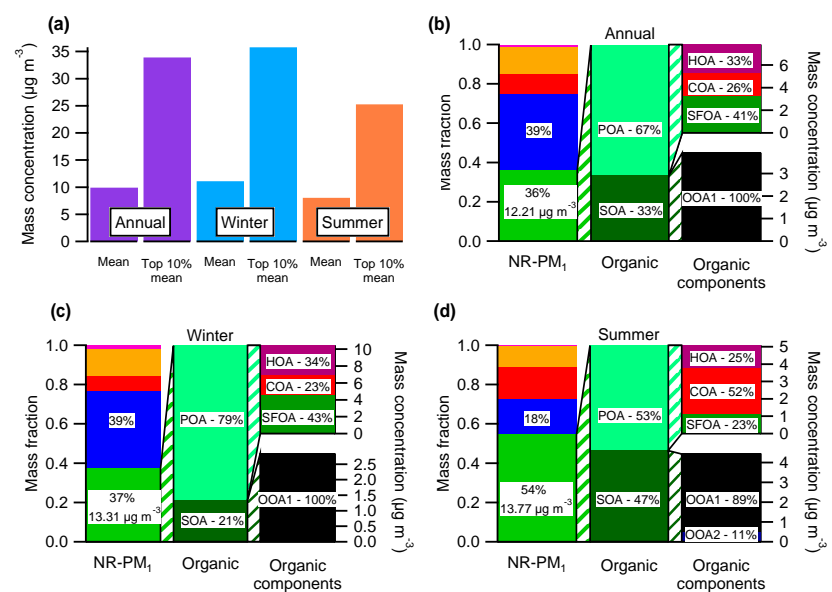

Figure 8. (a) Mean concentrations of the full calendar year (20122013), winter, and summer months. The average concentration of the top 10th percentile for the year as well as the top 10th percentile in the winter and summer are also shown. (b) Average fractional contributions of all species to the top 10th percentile for the year, with an expansion of the organic fraction into each of its primary and secondary components. (c) Average fractional contributions of all species to the top 10th percentile in the winter, with an expansion of the organic fraction into each of its primary and secondary components. (d) Average fractional contributions of all species to the top 10th percentile in the summer, with an expansion of the organic fraction into each of its primary and secondary components. In all figures, SFOA and OOA2 refer to $\mathrm{SFOA}_{\text {mod }}$ and OOA2 $2_{\text {mod }}$ respectively. Note that the PMF data (middle and right bars) do not include the summer period as detailed in Sect. 4.1 as well as Sects. 4.1 and 4.2 in the Supplement.

than may be previously supposed, as the range of precursors and processes appears to lead to consistent average characteristics.

\section{Pollution events in London}

Acute and short-term exposures to particulates have been associated with various adverse health effects including cardiovascular mortality as well as exacerbating existing illnesses such as pulmonary disease (Pope and Dockery, 2006, and references therein). It is therefore important to investigate episodic pollution events to better understand their effects on human health. During 2012, the average total NR-PM ${ }_{1}$ concentration ( \pm 1 standard deviation) was 9.91 $( \pm 10.39) \mu \mathrm{g} \mathrm{m}^{-3}$ in London, with slightly higher concentrations in the winter than summer (Fig. 8a). Several pollution events occurred throughout the year where the contributions to the high concentrations differed for each of the NR-PM components depending on the time of year. To determine whether emissions or atmospheric processes are the controlling factor in driving such high concentration events, the contributions of the different species to the top 10th percentile of the total annual concentration are assessed (Fig. 8a and b). 
Furthermore, the top 10th percentile of the winter and summer periods (Fig. 8c and d, respectively) are also analysed to evaluate any seasonal changes in the dominant species and sources.

Secondary aerosols are found to dominate throughout the year (Fig. 8b), irrespective of season, although the individual contributions from SIA and SOA change between winter and summer (Fig. 8c and d). High concentration events are dominated by nitrate in the winter (39\%), with a greater contribution from POA than SOA to the organic fraction (79 and $21 \%$ respectively). Furthermore, $\mathrm{SFOA}_{\text {mod }}$ is the greatest component of POA (43\%) and total organic fraction (34\%). In contrast, the high concentration events in summer are dominated by organics (54\%), with a significant contribution from SOA (47\%), although POA is still the dominant component of the organic fraction $(53 \%)$. Nevertheless, the largest contribution to the organic fraction is from OOA1 (42\%).

Pollution events in the winter are therefore driven by particulate emissions, especially nitrate and SFOA, whereas in the summer greater photochemistry results in higher concentrations predominantly comprised of SOA. Furthermore, the average mass of the pollution events in the winter is greater than that of the summer, suggesting that the limits for daily average concentrations, set to improve air quality and protect human health, are more likely to be exceeded in the winter than summer. Therefore, moderating sources of particulates is likely to be the most effective way of reducing particulates in the winter, although this does not consider the refractory sources of aerosol, such as black carbon, which contribute to the total PM mass in urban areas (e.g. Liu et al., 2014).

\section{Conclusions}

A full calendar year of NR-PM 1 chemical composition data were acquired using a cToF-AMS at an urban background site in North Kensington, London, where secondary aerosols comprise approximately $71 \%$ of the total non-refractory submicron mass. Nitrate exhibited strong seasonality, peaking in the spring as a result of favourable local meteorological conditions and a peak in ammonia emissions. Several high nitrate concentration events occurred throughout the year, which were the result of a combination of ambient conditions, availability of precursors, and air mass trajectory. Contrastingly, sulphate concentrations in London are predominantly influenced by regional pollution with few or no local sources and ammonium concentrations are governed by the availability of precursor emissions and meteorological conditions. Non-refractory chloride concentrations peak in the winter, governed by the lower temperatures favouring ammonium chloride partitioning to the aerosol phase.

The organic fraction was separated into five factors using PMF analysis: HOA, COA, SFOAPMF, OOA1, and

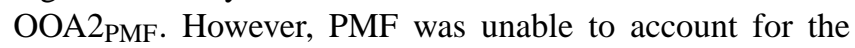
variance of two factors across the year, resulting in the as- signment of some SFOAPMF mass to OOAPMF as indicated by comparison of the factors derived from CToF-PMF and HR-PMF during the winter IOP. Based on the relationship between $\mathrm{SFOA}_{\mathrm{PMF}}$ and $\mathrm{OOA} 2 \mathrm{PMF}$ from the winter at the start and end of 2012, daily concentrations of $\mathrm{SFOA}_{\text {mod }}$ and OOA $2_{\text {mod }}$ were calculated for the year. OOA 1 exhibited characteristics consistent with regional behaviour whereas OOA $2_{\text {mod }}$ exhibited a seasonal trend typical of SOA, peaking in the summer when VOC emissions and photochemistry are greatest.

Although there is a substantial change in the concentration of SOA through the year, the extent of oxidation of the SOA, as defined by the oxygen content of organic aerosol mass, shows no variability as a function of time of year, air mass history, or temperature at the site. This suggests that in the urban background of London the range of precursors and chemical processing are insufficiently variable to yield secondary organic aerosol that has been exposed to significantly different levels of chemical processing. This is surprising given the variation in precursors throughout the year and the strong annual cycle in photochemical activity. However, this could make characterisation of SOA in urban environments more straightforward than may be previously supposed, as the range of precursors and processes appears to lead to consistent average characteristics.

Several high concentration events occurred in London during 2012, driven by particulate emissions in the winter and formation of SOA in the summer due to the greater photochemistry. The limits for daily average concentrations set to improve air quality and protect human health are more likely to be exceeded in the winter as the events had a greater average mass than those in summer. Moderating sources of nitrate and POA is likely to be the most effective way of reducing particulates in the winter, and due to the dominance of this season to the annual mean, for the whole year. SFOA, COA, and HOA all make a substantial contribution to the POA fraction; however, SFOA and COA are less well characterised than HOA so their variability requires further investigation.

\section{The Supplement related to this article is available online at doi:10.5194/acp-15-6351-2015-supplement.}

Acknowledgements. This work was supported in part by the UK Natural Environment Research Council (NERC) ClearfLo project [grant ref. NE/H008136/1] and co-ordinated by the National Centre for Atmospheric Science (NCAS). Additional support for the aerosol measurements was provided by the Department of Environment, Food and Rural Affairs (DEFRA). D. E. Young was supported by a NERC PhD studentship [ref. NE/I528142/1]. The authors would like to thank Anja Tremper at King's College London for assisting with instrument maintenance and James Lee from NCAS at the University of York for logistical assistance at 
the North Kensington supersite during the IOPs. Additional thanks to the Sion Manning School in North Kensington and adjacent community centre.

Edited by: H. Saathoff

\section{References}

Abdalmogith, S. S. and Harrison, R. M.: The use of trajectory cluster analysis to examine the long-range transport of secondary inorganic aerosol in the UK, Atmos. Environ., 39, 6686-6695, doi:10.1016/j.atmosenv.2005.07.059, 2005.

Abdalmogith, S. S. and Harrison, R. M.: An analysis of spatial and temporal properties of daily sulphate, nitrate and chloride concentrations at UK urban and rural sites, J. Environ. Monitor., 8, 691-699, 2006.

Aiken, A. C., DeCarlo, P. F., Kroll, J. H., Worsnop, D. R., Huffman, J. A., Docherty, K. S., Ulbrich, I. M., Mohr, C., Kimmel, J. R., Sueper, D., Sun, Y., Zhang, Q., Trimborn, A., Northway, M., Ziemann, P. J., Canagaratna, M. R., Onasch, T. B., Alfarra, M. R., Prevot, A. S. H., Dommen, J., Duplissy, J., Metzger, A., Baltensperger, U., and Jimenez, J. L.: O/C and OM/OC ratios of primary, secondary, and ambient organic aerosols with high resolution time-of-flight aerosol mass spectrometry, Environ. Sci. Technol., 42, 4478-4485, doi:10.1021/es703009q, 2008.

Allan, J. D., Jimenez, J. L., Williams, P. I., Alfarra, M. R., Bower, K. N., Jayne, J. T., Coe, H., and Worsnop, D. R.: Quantitative sampling using an Aerodyne aerosol mass spectrometer: 1. Techniques of data interpretation and error analysis, J. Geophys. Res.Atmos., 108, 4090, doi:10.1029/2002JD002358, 2003.

Allan, J. D., Williams, P. I., Morgan, W. T., Martin, C. L., Flynn, M. J., Lee, J., Nemitz, E., Phillips, G. J., Gallagher, M. W., and Coe, H.: Contributions from transport, solid fuel burning and cooking to primary organic aerosols in two UK cities, Atmos. Chem. Phys., 10, 647-668, doi:10.5194/acp-10-647-2010, 2010.

Ansari, A. S. and Pandis, S. N.: Response of Inorganic PM to Precursor Concentrations, Environ. Sci. Technol., 32, 2706-2714, 1998.

Aphekom Summary Report: Aphekom - Summary Report of the Aphekom Project 2008-2011, 2011.

AQEG: Fine particulate matter $\left(\mathrm{PM}_{2.5}\right)$ in the United Kingdom, $\mathrm{Re}$ port of the UK Air Quality Expert Group. Prepared for: Department for Environment, Food and Rural Affairs; Scottish Executive; Welsh Government; and Department of the Environment in Northern Ireland, 2012.

Bigi, A. and Harrison, R. M.: Analysis of the air pollution climate at a central urban background site, Atmos. Environ., 44, 20042012, 2010.

Bohnenstengel, S. I., Belcher, S. E., Aiken, A. C., Allan, J. D., Allen, G., Bacak, A., Bannan, T. J., Barlow, J. F., Beddows, D. C. S., Bloss, W. J., Booth, A. M., Chemel, C., Coceal, O., Di Marco, C. F., Mavendra, D. K., Faloon, K. H., Fleming, Z., Furger, M., Geitl, J. K., Graves, R. R., Green, D. C., Grimmond, C. S. B., Halios, C., Hamilton, J. F., Harrison, R. M., Heal, M. R., Heard, D. E., Helfter, C., Herndon, S. C., Holmes, R. E., Hopkins, J. R., Jones, A. M., Kelly, F. J., Kotthaus, S., Langford, B., Lee, J. D., Leigh, R. J., Lewis, A. C., Lidster, R. T., Lopez-Hilfiker, F. D., McQuaid, J. B., Mohr, C., Monks, P. S., Nemitz, E., Ng, N. L.,
Percival, C. J., Prévôt, A. S. H., Ricketts, H. M. A., Sokhi, R., Stone, D., Thornton, J. A., Tremper, A. H., Valach, A. C., Visser, S., Whalley, L. K., Williams, L. R., Xu, L., Young, D. E., and Zotter, P.: Meteorology, air quality and health in London: The ClearfLo project, B. Am. Meteorol. Soc., in press, 2014.

Boucher, O., Randall, D., Artaxo, P., Bretherton, C., Feingold, G., Forster, P., Kerminen, V.-M., Kondo, Y., Liao, H., Lohmann, U., Rasch, P., Satheesh, S. K., Sherwood, S., Stevens, B., and Zhang, X. Y.: Clouds and Aerosols, in: Climate Change 2013: The Physical Science Basis. Contribution of Working Group I to the Fifth Assessment Report of the Intergovernmental Panel on Climate Change, edited by: Stocker, T. F., Qin, D., Plattner, G.-K., Tignor, M., Allen, S. K., Boschung, J., Nauels, A., Xia, Y., Bex, V., and Midgley, P. M., Cambridge University Press, Cambridge, United Kingdom and New York, NY, USA, 2013.

Bressi, M., Sciare, J., Ghersi, V., Bonnaire, N., Nicolas, J. B., Petit, J.-E., Moukhtar, S., Rosso, A., Mihalopoulos, N., and Féron, A.: A one-year comprehensive chemical characterisation of fine aerosol $\left(\mathrm{PM}_{2.5}\right)$ at urban, suburban and rural background sites in the region of Paris (France), Atmos. Chem. Phys., 13, 78257844, doi:10.5194/acp-13-7825-2013, 2013.

Canagaratna, M. R., Jayne, J. T., Jimenez, J. L., Allan, J. D., Alfarra, M. R., Zhang, Q., Onasch, T. B., Drewnick, F., Coe, H., Middlebrook, A., Delia, A. E., Williams, L. R., Trimborn, A. M., Northway, M. J., Decarlo, P. F., Kolb, C. E., Davidovits, P., and Worsnop, D. R.: Chemical and microphysical characterization of ambient aerosols with the aerodyne aerosol mass spectrometer, Mass Spectrom. Rev., 26, 185-222, doi:10.1002/mas.20115, 2007.

Canonaco, F., Crippa, M., Slowik, J. G., Baltensperger, U., and Prévôt, A. S. H.: SoFi, an IGOR-based interface for the efficient use of the generalized multilinear engine (ME-2) for the source apportionment: ME-2 application to aerosol mass spectrometer data, Atmos. Meas. Tech., 6, 3649-3661, doi:10.5194/amt6-3649-2013, 2013.

Charron, A., Harrison, R. M., and Quincey, P.: What are the sources and conditions responsible for exceedences of the $24 \mathrm{~h} \mathrm{PM}_{10}$ limit value $\left(50 \mu \mathrm{g} \mathrm{m}^{-3}\right)$ at a heavily trafficked London site?, Atmos. Environ., 41, 1960-1975, 2007.

Crippa, M., DeCarlo, P. F., Slowik, J. G., Mohr, C., Heringa, M. F., Chirico, R., Poulain, L., Freutel, F., Sciare, J., Cozic, J., Di Marco, C. F., Elsasser, M., Nicolas, J. B., Marchand, N., Abidi, E., Wiedensohler, A., Drewnick, F., Schneider, J., Borrmann, S., Nemitz, E., Zimmermann, R., Jaffrezo, J.-L., Prévôt, A. S. H., and Baltensperger, U.: Wintertime aerosol chemical composition and source apportionment of the organic fraction in the metropolitan area of Paris, Atmos. Chem. Phys., 13, 961-981, doi:10.5194/acp-13-961-2013, 2013a.

Crippa, M., Canonaco, F., Slowik, J. G., El Haddad, I., DeCarlo, P. F., Mohr, C., Heringa, M. F., Chirico, R., Marchand, N., Temime-Roussel, B., Abidi, E., Poulain, L., Wiedensohler, A., Baltensperger, U., and Prévôt, A. S. H.: Primary and secondary organic aerosol origin by combined gas-particle phase source apportionment, Atmos. Chem. Phys., 13, 8411-8426, doi:10.5194/acp-13-8411-2013, 2013 b.

Cross, E. S., Slowik, J. G., Davidovits, P., Allan, J. D., Worsnop, D. R., Jayne, J. T., Lewis, D. K., Canagaratna, M., and Onasch, T. B.: Laboratory and ambient particle density determinations using 
light scattering in conjunction with aerosol mass spectrometry, Aerosol Sci. Tech., 41, 343-359, 2007.

Dall'Osto, M., Ovadnevaite, J., Ceburnis, D., Martin, D., Healy, R. M., O'Connor, I. P., Kourtchev, I., Sodeau, J. R., Wenger, J. C., and O'Dowd, C.: Characterization of urban aerosol in Cork city (Ireland) using aerosol mass spectrometry, Atmos. Chem. Phys., 13, 4997-5015, doi:10.5194/acp-13-4997-2013, 2013.

DeCarlo, P. F., Kimmel, J. R., Trimborn, A., Northway, M. J., Jayne, J. T., Aiken, A. C., Gonin, M., Fuhrer, K., Horvath, T., Docherty, K. S., Worsnop, D. R., and Jimenez, J. L.: Field-deployable, high-resolution, time-of-flight aerosol mass spectrometer, Anal. Chem., 78, 8281-8289, doi:10.1021/ac061249n, 2006.

DeCarlo, P. F., Dunlea, E. J., Kimmel, J. R., Aiken, A. C., Sueper, D., Crounse, J., Wennberg, P. O., Emmons, L., Shinozuka, Y., Clarke, A., Zhou, J., Tomlinson, J., Collins, D. R., Knapp, D., Weinheimer, A. J., Montzka, D. D., Campos, T., and Jimenez, J. L.: Fast airborne aerosol size and chemistry measurements above Mexico City and Central Mexico during the MILAGRO campaign, Atmos. Chem. Phys., 8, 4027-4048, doi:10.5194/acp-84027-2008, 2008.

Donahue, N. M., Kroll, J. H., Pandis, S. N., and Robinson, A. L.: A two-dimensional volatility basis set - Part 2: Diagnostics of organic-aerosol evolution, Atmos. Chem. Phys., 12, 615-634, doi:10.5194/acp-12-615-2012, 2012.

Drewnick, F., Hings, S. S., Decarlo, P. F., Jayne, J. T., Gonin, M., Fuhrer, K., Weimer, S., Jimenez, J. L., Demerjian, K. L., Borrmann, S., and Worsnop, D. R.: A new time-of-flight aerosol mass spectrometer (TOF-AMS) - Instrument description and first field deployment, Aerosol Sci. Tech., 39, 637-658, doi:10.1080/02786820500182040, 2005.

Dunmore, R. E., Hopkins, J. R., Lidster, R. T., Lee, J. D., Evans, M. J., Rickard, A. R., Lewis, A. C., and Hamilton, J. F.: Dieselrelated hydrocarbons can dominate gas phase reactive carbon in megacities, Atmos. Chem. Phys. Discuss., 15, 9541-9571, doi::10.5194/acpd-15-9541-2015, 2015.

EEA: The European environment - state and outlook 2010: synthesis, European Environment Agency, Copenhagen, 2010.

European Union: Directive 2008/50/EC of the European parliament and of the council of 21 May 2008 on ambient air quality and cleaner air for Europe, Official Journal of the European Union, L152, 2008.

El Haddad, I., Marchand, N., D’Anna, B., Jaffrezo, J.-L., and Wortham, H.: Functional group composition of organic aerosol from combustion emissions and secondary processes at two contrasted urban environments, Atmos. Environ., 75, 308-320, doi:10.1016/j.atmosenv.2013.04.019, 2013.

Freutel, F., Schneider, J., Drewnick, F., von der Weiden-Reinmüller, S.-L., Crippa, M., Prévôt, A. S. H., Baltensperger, U., Poulain, L., Wiedensohler, A., Sciare, J., Sarda-Estève, R., Burkhart, J. F., Eckhardt, S., Stohl, A., Gros, V., Colomb, A., Michoud, V., Doussin, J. F., Borbon, A., Haeffelin, M., Morille, Y., Beekmann, M., and Borrmann, S.: Aerosol particle measurements at three stationary sites in the megacity of Paris during summer 2009: meteorology and air mass origin dominate aerosol particle composition and size distribution, Atmos. Chem. Phys., 13, 933-959, doi:10.5194/acp-13-933-2013, 2013.

Goldstein, A. H. and Galbally, I. E.: Known and unexplored organic constituents in the Earth's atmosphere, Environ. Sci. Technol., 41, 1515-1521, 2007.
Harrison, R. M., Dall'Osto, M., Beddows, D. C. S., Thorpe, A. J., Bloss, W. J., Allan, J. D., Coe, H., Dorsey, J. R., Gallagher, M., Martin, C., Whitehead, J., Williams, P. I., Jones, R. L., Langridge, J. M., Benton, A. K., Ball, S. M., Langford, B., Hewitt, C. N., Davison, B., Martin, D., Petersson, K. F., Henshaw, S. J., White, I. R., Shallcross, D. E., Barlow, J. F., Dunbar, T., Davies, F., Nemitz, E., Phillips, G. J., Helfter, C., Di Marco, C. F., and Smith, S.: Atmospheric chemistry and physics in the atmosphere of a developed megacity (London): an overview of the REPARTEE experiment and its conclusions, Atmos. Chem. Phys., 12, 3065-3114, doi:10.5194/acp-12-3065-2012, 2012.

Harrison, R. M. and Yin, J.: Sources and processes affecting carbonaceous aerosol in central England, Atmos. Environ., 42, 1413-1423, 2008.

Huang, R.-J., Zhang, Y., Bozzetti, C., Ho, K.-F., Cao, J.-J., Han, Y., Daellenbach, K. R., Slowik, J. G., Platt, S. M., Canonaco, F., Zotter, P., Wolf, R., Pieber, S. M., Bruns, E. A., Crippa, M., Ciarelli, G.., Piazzalunga, A., Schwikowski, M., Abbaszade, G., SchnelleKreis, J., Zimmerman, R., An, Z., Szidat, S., Baltensperger, R., El Haddad, I. and Prévôt, A. S. H.: High secondary aerosol contribution to particulate pollution during haze events in China, Nature, 514, 218-222, doi:10.1038/nature13774, 2014.

Heald, C. L., Kroll, J. H., Jimenez, J. L., Docherty, K. S., DeCarlo, P. F., Aiken, A. C., Chen, Q., Martin, S. T., Farmer, D. K., and Artaxo, P.: A simplified description of the evolution of organic aerosol composition in the atmosphere, Geophys. Res. Lett., 37, L08803, doi:10.1029/2010GL042737, 2010.

Huffman, J. A., Ziemann, P. J., Jayne, J. T., Worsnop, D. R., and Jimenez, J. L.: Development and Characterization of a FastStepping/Scanning Thermodenuder for Chemically-Resolved Aerosol Volatility Measurements, Aerosol Sci. Technol., 42, 395-407, 2008.

Jayne, J. T., Leard, D. C., Zhang, X. F., Davidovits, P., Smith, K. A., Kolb, C. E., and Worsnop, D. R.: Development of an aerosol mass spectrometer for size and composition analysis of submicron particles, Aerosol Sci. Tech., 33, 49-70, doi:10.1080/027868200410840, 2000.

Jimenez, J. L., Canagaratna, M. R., Donahue, N. M., Prevot, A. S. H., Zhang, Q., Kroll, J. H., Decarlo, P. F., Allan, J. D., Coe, H., Ng, N. L., Aiken, A. C., Docherty, K. S., Ulbrich, I. M., Grieshop, A. P., Robinson, A. L., Duplissy, J., Smith, J. D., Wilson, K. R., Lanz, V. A., Hueglin, C., Sun, Y. L., Tian, J., Laaksonen, A., Raatikainen, T., Rautiainen, J., Vaattovaara, P., Ehn, M., Kulmala, M., Tomlinson, J. M., Collins, D. R., Cubison, M. J., E., Dunlea, E. J., Huffman, J. A., Onasch, T. B., Alfarra, M. R., Williams, P. I., Bower, K. N., Kondo, Y., Schneider, J., Drewnick, F., Bor- rmann, S., Weimer, S., Demerjian, K. L., Salcedo, D., Cottrell, L., Griffin, R., Takami, A., Miyoshi, T., Hatakeyama, S., Shimono, A., Sun, J. Y., Zhang, Y. M., Dzepina, K., Kimmel, J. R., Sueper, D., Jayne, J. T., Herndon, S. C., Trimborn, A. M., Williams, L. R., Wood, E. C., Middlebrook, A. M., Kolb, C. E., Baltensperger, U., and Worsnop, D. R.: Evolution of Organic Aerosols in the Atmosphere, Science, 326, 1525-1529, doi:10.1126/science.1180353, 2009.

Kroll, J. H., Donahue, N. M. Jimenez, J. L., Kessler, S. H., Canagaratna, M. R., Wilson, K. R., Altieri, K. E., Mazzoleni, L. R., Wozniak, A. S., Bluhm, H., Mysak, E. R., Smith, J. D., Kolb, C. E., and Worsnop, D. R.: Carbon Oxidation State as a Metric for 
Describing the Chemistry of Atmospheric Organic Aerosol, Nat. Chem., 3, 133-139, doi:10.1038/NCHEM.948, 2011.

Lanz, V. A., Alfarra, M. R., Baltensperger, U., Buchmann, B., Hueglin, C., and Prévôt, A. S. H.: Source apportionment of submicron organic aerosols at an urban site by factor analytical modelling of aerosol mass spectra, Atmos. Chem. Phys., 7, 15031522, doi:10.5194/acp-7-1503-2007, 2007.

Lanz, V. A., Alfarra, M. R., Baltensperger, U., Buchmann, B., Hueglin, C., Szidat, S., Wehrli, M. N., Wacker, L., Weimer, S., Caseiro, A., Puxbaum, H., and Prévôt, A. S. H.: Source attribution of submicron organic aerosols during wintertime inversions by advanced factor analysis of aerosol mass spectra, Environ. Sci. Technol., 42, 214-220, doi:10.1021/es0707207, 2008.

Liu, D., Allan, J. D., Young, D. E., Coe, H., Beddows, D., Fleming, Z. L., Flynn, M. J., Gallagher, M. W., Harrison, R. M., Lee, J., Prevot, A. S. H., Taylor, J. W., Yin, J., Williams, P. I., and Zotter, P.: Size distribution, mixing state and source apportionment of black carbon aerosol in London during wintertime, Atmos. Chem. Phys., 14, 10061-10084, doi:10.5194/acp14-10061-2014, 2014.

Martin, C. L., Allan, J. D., Crosier, J., Choularton, T. W., Coe, H., and Gallagher, M. W.: Seasonal variation of fine particulate composition in the centre of a UK city, Atmos. Environ., 45, 43794389, 10.1016/j.atmosenv.2011.05.050, 2011.

Megaritis, A. G., Fountoukis, C., Charalampidis, P. E., Pilinis, C., and Pandis, S. N.: Response of fine particulate matter concentrations to changes of emissions and temperature in Europe, Atmos. Chem. Phys., 13, 3423-3443, doi:10.5194/acp-13-34232013, 2013.

Middlebrook, A. M., Bahreini, R., Jimenez, J. L., and Canagaratna, M. R.: Evaluation of composition-dependent collection efficiencies for the Aerodyne aerosol mass spectrometer using field data, Aerosol. Sci. Tech., 46, 258-271, doi:10.1080/02786826.2011.620041, 2012.

Mohr, C., Huffman, J. A., Cubison, M. J., Aiken, A. C., Docherty, K. S., Kimmel, J. R., Ulbrich, I. M., Hannigan, M., Garcia, J., and Jimenez, J. L.: Characterization of Primary Organic Aerosol Emissions from Meat Cooking, Trash Burning, and Motor Vehicles with High-Resolution Aerosol Mass Spectrometry and Comparison with Ambient and Chamber Observations, Environ. Sci. Technol., 43, 2443-2449, doi:10.1021/es8011518, 2009.

Mohr, C., DeCarlo, P. F., Heringa, M. F., Chirico, R., Slowik, J. G., Richter, R., Reche, C., Alastuey, A., Querol, X., Seco, R., Peñuelas, J., Jiménez, J. L., Crippa, M., Zimmermann, R., Baltensperger, U., and Prévôt, A. S. H.: Identification and quantification of organic aerosol from cooking and other sources in Barcelona using aerosol mass spectrometer data, Atmos. Chem. Phys., 12, 1649-1665, doi:10.5194/acp-12-1649-2012, 2012.

Monks, P. S., Granier, C., Fuzzi, S., Stohl, A., Williams, M. L., Akimoto, H., Amann, M., Baklanov, A., Baltensperger, U., Bey, I., Blake, N., Blake, R. S., Carslaw, K. S., Cooper, O. R., Dentener, F. J., Fowler, D., Fragkou, E., Frost, G. J., Generoso, S., Ginoux, P., Grewe, V., Guenther, A., Hansson, H. C., Henne, S., Hjorth, J., Hofzumahaus, A., Huntrieser, H., Isaksen, I. S. A., Jenkin, M. E., Kaiser, J., Kanakidou, M., Klimont, Z., Kulmala, M., Laj, P., Lawrence, M. G., Lee, J. D., Liousse, C., Maione, M., McFiggans, G. B., Metzger, A., Mieville, A., Moussiopoulos, N., Orlando, J. J., O'Dowd, C. D., Palmer, P. I., Parrish, D. D., Petzold, A., Platt, U., Pöschl, U., Prévôt, A. S. H., Reeves, C. E.,
Reimann, S., Rudich, Y., Sellegri, K., Steinbrecher, R., Simpson, D., ten Brink, H., Theloke, J., van Der Werf, G. R., Vautard, R., Vestreng, V., Vlachokostas, C., and von Glasow, R.: Atmospheric composition change - global and regional air quality, Atmos. Environ., 43, 5268-5350, doi:10.1016/j.atmosenv.2009.08.021, 2009.

Morgan, W. T., Allan, J. D., Bower, K. N., Capes, G., Crosier, J., Williams, P. I., and Coe, H.: Vertical distribution of sub-micron aerosol chemical composition from North-Western Europe and the North-East Atlantic, Atmos. Chem. Phys., 9, 5389-5401, doi:10.5194/acp-9-5389-2009, 2009.

Morgan, W. T., Allan, J. D., Bower, K. N., Highwood, E. J., Liu, D., McMeeking, G. R., Northway, M. J., Williams, P. I., Krejci, R., and Coe, H.: Airborne measurements of the spatial distribution of aerosol chemical composition across Europe and evolution of the organic fraction, Atmos. Chem. Phys., 10, 4065-4083, doi:10.5194/acp-10-4065-2010, 2010.

NAEI (National atmospheric emissions inventory), available at: http://naei.defra.gov.uk/, last access: 24 December 2013.

Ng, N. L., Canagaratna, M. R., Zhang, Q., Jimenez, J. L., Tian, J., Ulbrich, I. M., Kroll, J. H., Docherty, K. S., Chhabra, P. S., Bahreini, R., Murphy, S. M., Seinfeld, J. H., Hildebrandt, L., Donahue, N. M., DeCarlo, P. F., Lanz, V. A., Prévôt, A. S. H., Dinar, E., Rudich, Y., and Worsnop, D. R.: Organic aerosol components observed in Northern Hemispheric datasets from Aerosol Mass Spectrometry, Atmos. Chem. Phys., 10, 46254641, doi:10.5194/acp-10-4625-2010, 2010.

Ng, N. L., Herndon, S. C., Trimborn, A., Canagaratna, M. R., Croteau, P., Onasch, T. M., Sueper, D., and Worsnop, D. R.: An Aerosol Chemical Speciation Monitor (ACSM) for routine monitoring of atmospheric aerosol composition, Aerosol Sci. Technol., 45, 770-784, 2011a.

Ng, N. L., Canagaratna, M. R., Jimenez, J. L., Chhabra, P. S., Seinfeld, J. H., and Worsnop, D. R.: Changes in organic aerosol composition with aging inferred from aerosol mass spectra, Atmos. Chem. Phys., 11, 6465-6474, doi:10.5194/acp-11-64652011, $2011 b$.

Oberdörster, G., Oberdörster, E., and Oberdörster, J.: Nanotoxicology: An emerging discipline evolving from studies of ultrafine particles, Environ. Health Persp., 113, 823-839, 2005.

Paatero, P. and Tapper, U.: Positive matrix factorization - a nonnegative factor model with optimal utilization of error-estimates of data values, Environmetrics, 5, 111-126, 1994.

Pope III, C. A. and Dockery, D. W.: Health Effects of Fine Particulate Air Pollution: Lines that Connect, J. Air Waste Manage., 56, 709-742, doi:10.1080/10473289.2006.10464485, 2006.

Pöschl, U.: Atmospheric aerosols: composition, transformation, climate and health effects, Angew. Chem. Int. Ed., 44, 7520-7540, 2005.

Schaap, M., van Loon, M., ten Brink, H. M., Dentener, F. J., and Builtjes, P. J. H.: Secondary inorganic aerosol simulations for Europe with special attention to nitrate, Atmos. Chem. Phys., 4, 857-874, doi:10.5194/acp-4-857-2004, 2004.

Seinfeld, J. H. and Pandis, S. N.: Atmospheric chemistry and physics: from air pollution to climate change, Second Edition, John Wiley \& Sons, New York, 2006.

Stelson, A. and Seinfeld, J.: Relative humidity and temperature dependence of the ammonium nitrate dissociation constant, Atmos. 
Environ., 16, 983-992, doi:10.1016/j.atmosenv.2007.10.063, 1982.

Sueper, D.: ToF-AMS High Resolution Analysis Software - Pika, online available at: http://cires.colorado.edu/jimenez-group/ ToFAMSResources/ToFSoftware/index.html (last access: 26 March 2015), 2008.

Sun, Y.-L., Zhang, Q., Schwab, J. J., Demerjian, K. L., Chen, W.N., Bae, M.-S., Hung, H.-M., Hogrefe, O., Frank, B., Rattigan, O. V., and Lin, Y.-C.: Characterization of the sources and processes of organic and inorganic aerosols in New York city with a high-resolution time-of-flight aerosol mass apectrometer, Atmos. Chem. Phys., 11, 1581-1602, doi:10.5194/acp-11-15812011, 2011.

Sun, Y. L., Wang, Z. F., Fu, P. Q., Yang, T., Jiang, Q., Dong, H. B., $\mathrm{Li}$, J., and Jia, J. J.: Aerosol composition, sources and processes during wintertime in Beijing, China, Atmos. Chem. Phys., 13, 4577-4592, doi:10.5194/acp-13-4577-2013, 2013.

Sutton, M. A., Dragosits, U. Tang, Y. S., and Fowler, D.: Ammonia emissions from non-agricultural sources in the UK, Atmos. Environ., 34, 855-869, 2000.

Takegawa, N., Miyakawa, T., Kondo, Y., Jimenez, J. L., Zhang, Q., Worsnop, D. R., and Fukuda, M.: Seasonal and diurnal variations of submicron organic aerosol in Tokyo observed using the Aerodyne aerosol mass spectrometer, J. Geophys. Res., 111, D11206, doi:10.1029/2005JD006515, 2006.

Ulbrich, I. M., Canagaratna, M. R., Zhang, Q., Worsnop, D. R., and Jimenez, J. L.: Interpretation of organic components from Positive Matrix Factorization of aerosol mass spectrometric data, Atmos. Chem. Phys., 9, 2891-2918, doi:10.5194/acp-9-2891-2009, 2009.
Wagener, S., Langner, M., Hansen, U., Moriske, H. J., and Endlicher, W. R.: Spatial and seasonal variations of biogenic tracer compounds in ambient $\mathrm{PM}_{10}$ and $\mathrm{PM}_{1}$ samples in Berlin, Germany, Atmos. Environ., 47, 33-42, 2012.

Watson, J. G.: Visibility: Science and Regulation, J. Air Waste Manage., 52, 628-713, doi:10.1080/10473289.2002.10470813, 2002.

WHO: Air Quality Guidelines. Global update 2005. Particulate matter, ozone, nitrogen dioxide and sulphur dioxide. World Health Organization European Office, Copenhagen, 2005.

Yin, J., Harrison, R. M., Chen, Q., Rutter, A., and Schauer, J. J.: Source apportionment of fine particles at urban background and rural sites in the UK Atmosphere, Atmos. Environ., 44, 841-851, 2010.

Zhang, Q., Jimenez, J. L., Canagaratna, M. R., Allan, J. D., Coe, H., Ulbrich, I., Alfarra, M. R., Takami, A., Middlebrook, A. M., Sun, Y. L., Dzepina, K., Dunlea, E. J., Docherty, K. S., Decarlo, P. F., Salcedo, D., Onasch, T., Jayne, J. T., Miyoshi, T., Shimono, A., Hatakeyama, S., Takegawa, N., Kondo, Y., Schneider, J., Drewnick, F., Borrmann, S., Weimer, S., Demerjian, K. L., Williams, P., Bower, K. N., Bahreini, R., Cottrell, L., Griffin, R. J., Rautiainen, J., Sun, J. Y., Zhang, Y. M., and Worsnop, D. R.: Ubiquity and dominance of oxygenated species in organic aerosols in anthropogenically-influenced Northern Hemisphere midlatitudes, Geophys. Res. Lett., 34, L13801, doi:10.1029/2007GL029979, 2007. 